OPEN ACCESS

Edited by:

Gary S. Kleppel,

University at Albany, United States

Reviewed by:

Yiorgos Gadanakis,

University of Reading,

United Kingdom

Caroline B. G. Cartier,

University at Albany, United States

${ }^{*}$ Correspondence:

Bertrand Dumont bertrand.dumont@inrae.fr

Specialty section: This article was submitted to Agroecology and Ecosystem

Services,

a section of the journal Frontiers in Sustainable Food

Systems

Received: 20 March 2020

Accepted: 16 June 2020

Published: 16 July 2020

Citation:

Dumont B, Puillet L, Martin G Savietto $D$, Aubin J, Ingrand $S$,

Niderkorn V, Steinmetz $L$ and Thomas M (2020) Incorporating

Diversity Into Animal Production

Systems Can Increase Their Performance and Strengthen Their Resilience.

Front. Sustain. Food Syst. 4:109, doi: 10.3389/fsufs.2020.00109

\section{Incorporating Diversity Into Animal Production Systems Can Increase Their Performance and Strengthen Their Resilience}

\author{
Bertrand Dumont ${ }^{1 *}$, Laurence Puillet ${ }^{2}$, Guillaume Martin ${ }^{3}$, Davi Savietto ${ }^{4}$, Joël Aubin ${ }^{5}$, \\ Stéphane Ingrand ${ }^{6}$, Vincent Niderkorn ${ }^{1}$, Lucille Steinmetz ${ }^{1}$ and Marielle Thomas $^{7}$ \\ ${ }^{1}$ INRAE, VetAgro Sup, UMR Herbivores, Université Clermont Auvergne, Saint-Genès-Champanelle, France, ${ }^{2}$ Université \\ Paris-Saclay, INRAE, AgroParis Tech, UMR Modélisation Systémique Appliquée aux Ruminants, Université Paris-Saclay, \\ Paris, France, ${ }^{3}$ A GIR, Université de Toulouse, INRAE, INP, Castanet-Tolosan, France, ${ }^{4}$ GenPhySE, Université de Toulouse, \\ INRAE, INP, ENVT, Castanet-Tolosan, France, ${ }^{5}$ INRAE, UMR Sol Agro et Hydrosystème Spatialisation, Rennes, France, \\ ${ }^{6}$ AgroParis Tech, INRAE, VetAgro Sup, UMR Territoires, Université Clermont Auvergne, Clermont-Ferrand, France, ${ }^{7}$ INRAE, \\ UR Animal et Fonctionnalités des Produits Animaux, Université de Lorraine, Nancy, France
}

Animal production systems (APSs) have long been transformed through intensification, specialization and geographical concentration, leading them to become major anthropogenic drivers of pollution, climate change, and biodiversity loss. Agroecology, organic farming and sustainable intensification have been proposed as alternative models to invert those trends. Diversity is highly valued in agroecology and organic farming, in which it is assumed not only to increase farm performance but also to strengthen farm resilience. Here, we examine how the diversity of system components and interactions among these components can increase productivity, resource-use efficiency and farm resilience in aquaculture, rabbit, monogastric and ruminant systems. In doing so, we reveal that the same processes can occur in very different systems. For instance, the higher performance of multi-species aquaculture or ruminant grazing systems results from (i) the complementary feeding habits of animal species that exploit resources from different ecological niches more efficiently; and (ii) facilitation or competitive exclusion, which results in a species increasing or decreasing resource availability for another species. The benefits of diversity are observed not only in relatively extensive systems but also in intensive indoor systems. For instance, genetic diversity is associated with herd and social immunity in rabbit production, while trade-offs between life functions play a major role in dairy herd performance. In the last section, we discuss how management options nested in system component diversity and their interactions can enhance system resilience. Strategic and tactical management of APS diversity can promote farm buffering and adaptive capabilities, respectively, via the abovementioned processes. By stabilizing the farm financial situation and facilitating access to short supply channels, transformative changes, such as a diversification of the animal species bred or development of a processing enterprise on farm, expand options for increasing 
the resilience of APSs to market price fluctuations and climatic shocks. However, the need for new technical skills and sometimes high initial investments can act as strong inhibitors of farm diversification. We conclude with a description of some of the research or action that is needed for these principles to be more widely implemented in commercial farms.

Keywords: agroecology, aquaculture, grazing, livestock, management

\section{INTRODUCTION}

The livestock sector has received particular attention in the news and scientific media and is considered a major anthropogenic driver of climate change, water pollution, and biodiversity losses. Although the best transition options are still strongly debated, there is a consensus on the need for animal production systems (APSs) to reduce the use of inputs, to emit less greenhouse gasses (GHG) and to increase their mitigation potential, e.g., through carbon sequestration in grassland and crop soils (Food Agriculture and Organisation, 2013). Over the past 60 years, APSs have been primarily transformed through the top-down structuring of linear value chains, intensification, specialization and geographical concentration (Thornton, 2010). When intensification and specialization were the two primary drivers of APSs, the focus was primarily on short-term efficiency to make the best use of high-yielding breeds and cultivars under optimal production conditions. Intensification led to a dramatic reduction in within-system diversity, i.e., the diversity of animal species and breeds, the genetic diversity within breeds, the diversity of feed resources, and even the diversity of management practices. Recently, the methods (van der Werf et al., 2020) and frameworks (Ryschawy et al., 2019) for analyzing system sustainability have increasingly accounted for a wider perspective on the functions and services livestock farming systems provide to society. A number of these functions and ecosystem services (recycling of nutrients, forage yield, pollination, etc.) are closely linked to agrobiodiversity, and their persistence depends largely on maintaining biological diversity in APSs (Kremen et al., 2012; Carvalho et al., 2018; Haughey et al., 2018; Wang et al., 2019; Yang et al., 2019).

Incorporating diversity in APSs is thus highly valued in agroecology (Dumont et al., 2013, 2018) and organic farming (Ponisio et al., 2015) the two main forms of APSs that attempt to step away from highly specialized conventional models. Sustainable intensification of tropical forage-based systems is likely to increase their productivity, while saving land from further deforestation (Silva et al., 2017; zu Ermgassen et al., 2018). Incorporating diversity in these systems mainly relies on the integration of forage leys into cropping systems to enhance the coupling of carbon and nitrogen cycles within grasslands and soils, while minimizing environmental losses toward the atmosphere and hydrosphere (Carvalho et al., 2018; Dumont et al., 2018). Beyond this, the value of diversity in agroecological or organic farming systems is based on the need to fortify their internal capacity to face perturbations because these systems are not secured with external inputs (e.g., concentrated feed and veterinary products) as they are in conventional systems
(Bommarco et al., 2013). For instance, individual response variability and interactions among system components could enhance the long-term herd (Blanc et al., 2013; Magne et al., 2016) and system performances (Tichit et al., 2011; Kremen et al., 2012; Ponisio et al., 2015; Diakité et al., 2019). In addition, rearing different species in a pastoral system could be seen as a riskspreading strategy against disease outbreaks, feed shortages and market price fluctuations (Mace, 1990; Nozières et al., 2011; Joly et al., 2019). Within-farm diversity is thus assumed to affect not only the system's productive yield but also its stability and ability to cope with uncertainty (Altieri et al., 2015; Sneessens et al., 2019). Therefore, the primary outcome related to an increase in system diversity may be an increase in system resilience.

Resilience focuses on the capacity of a system to absorb perturbations and reorganize while undergoing changes to maintain its function (Walker et al., 2004). As a system is indeed not organized around a unique equilibrium, Darnhofer (2014) discussed that resilience covers the buffer, adaptive and transformative capabilities of a given system. Buffer capability denotes the ability of a system to assimilate a perturbation without changing its structure or function; adaptive capability, that of adjusting to change while staying in the current stability domain; and transformative capability implies transition to a new system. These three capabilities may also operate in synergy at the farm scale since gradual and marginal changes may accumulate and, ultimately, hinder a transformative change (Darnhofer, 2014; Vermeulen et al., 2018). Among the underlying mechanisms, the 'portfolio effect' states that communities with high species diversity are likely to include complementary species that can adapt to any condition of a fluctuating environment. Consequently, the number of species per se would have a positive effect on the system resilience (Figge, 2004; Volaire et al., 2014). Functional diversity is also likely to increase system resilience through redundancy mechanisms since the collapse of any species can be offset by another species with similar characteristics (Biggs et al., 2012).

Thus, at this stage, we have knowledge of the underlying mechanisms supporting farm resilience properties and theoretical assumptions on the role of diversity for resilience. However, as there is a lack of experimental evidence, it is far from clear how these concepts are applicable in different types of APSs. In this paper, we therefore examine empirical evidence and model outputs related to how within-farm diversity can enhance the production of goods and services and strengthen farm resilience in APSs with different types of productions covering a large gradient of intensification (i.e., relying on increasing levels of inputs to produce food on a given area of land). In the first section, we focus on the mechanisms expressed 
within the system components, including grassland diversity and the inter-individual variability between animals in herds and flocks. In the second section, we focus on interactions between system components and analyze how appropriate combinations of plant and animal production and of livestock species can increase farm production and benefit animal health. In the third section, we address how to manage system resilience by discussing how the capabilities proposed by Darnhofer (2014) could be enhanced by farm-scale diversity. Integrating economic and social dimensions through sales management and farmers' securitization strategies results in a broader analysis of how farm-scale diversity allows for the adaptation of APSs to risks and uncertainties.

\section{VALUING DIVERSITY OF SYSTEM COMPONENTS}

\section{Grasslands}

There has been an important research effort to determine how multispecies grasslands could benefit sward productivity, animal performance, and farm fodder autonomy and resilience in grassland-based systems. A review by Cardinale et al. (2007) revealed that mixtures of species produce an average of 1.7 times more biomass than that of species monocultures. These authors also showed that the contribution of biological processes involving multiple species equals or exceeds the contribution of the most productive species, with an increase over time. Finn et al. (2013) extended this result to the case of intensively managed temperate grasslands; the yields of pastures made up of a variety of annual species was 30\% higher than those of pastures that only had a single annual species and exceeded those of the best monoculture in approximately $60 \%$ of the sites (Figure 1). Finn et al. (2013) attributed this higher yield to the complementarity of the resource acquisition (e.g., nitrogen capture by $\mathrm{N}_{2}$-fixing legumes and rooting depth) and conservation strategies among plant species. In ecology, traits related to leaf functions such as photosynthesis efficiency, carbohydrate metabolism, nitrogen consumption allow plant species to be ranked according to their strategies for the acquisition and conservation of resources (Wright et al., 2004). These mixtures benefited from the presence of grasses that rapidly acquire supplied $\mathrm{N}$, and maintained resistance to weed invasion for at least 3 years. Plant diversity also secures the system against seasonal and long-term climatic variability by limiting the impacts of climatic disturbance on forage yield and by increasing grassland resilience to drought conditions (Volaire et al., 2014). This results from the complementarity of plant traits and strategies, such as dehydration avoidance, dehydration tolerance and summer dormancy, within species-rich communities. Yield stability also increased when a plant species assemblage increased from one to four species in intensively managed swards, under drought and post-drought periods of two consecutive years. This is likely due to the high degree of species asynchrony increasing the temporal stability (Haughey et al., 2018).

Rotationally grazing on sown swards with increasing botanical complexity (in terms of the number of species and functional types) has been shown to improve animal performance in dairy cows (Roca-Fernández et al., 2016) and sheep (Grace et al., 2019). Grazing sheep on multispecies swards reduced the requirements for mineral fertilization and chemical anthelmintics, due to the availability of $\mathrm{N}$-fixing legumes and the presence of tannin-rich plants, respectively (Grace et al., 2019). In dairy cows, improved animal performance resulted from the cumulative effect of improved pasture nutritive value and increased daily intake (Roca-Fernández et al., 2016). Such an increase in daily intake happens through a higher feeding motivation in association with a more diverse diet (Ginane et al., 2002) rather than through associative effects between grasses and legumes on dry matter digestibility (Niderkorn et al., 2017). Diversified natural grasslands also have the potential to combine high digestibility with a reduction in enteric methane and nitrogen losses in urine (Macheboeuf et al., 2014). Knowledge of the individual and associative effects of plants containing bioactive compounds (polyphenolic compounds, alkaloids, and terpene compounds) is still scarce. Some legumes containing condensed tannins, including species such as Onobrychis viciifolia and Hedysarum coronarium, have also been used to control strongyle larval development in small ruminants (Hoste et al., 2006) and horses (Collas et al., 2018) but these compounds are toxic to animals when consumed in large amounts. Further research is thus needed to balance their positive and toxic effects in a way that benefits animal health and performance without impairing their digestive efficiency.

\section{Animal Inter-Individual Variability}

The intrinsic individual variability in animals within a herd or a flock is a source of diversity, which has a key role in the production process (Tichit et al., 2011) and may also have positive effects on system resilience. Such positive effects are grounded in the diversity of the trade-offs between life functions that induce specific adaptive responses of animals to suboptimal environments. For instance, a multi-trait and dynamic method was proposed by Ollion et al. (2016) to describe the trade-offs between life functions in dairy cows. These authors used phenotypic traits during the first 13 weeks postpartum, when dairy cows experience a negative energy balance, and distinguished four trade-off profiles independently of the cattle breed (i.e., Holstein, Montbéliarde and Normande) and cow age (parity order). Profile one ( $n=53$ cows) corresponded to high yielding cows [average weekly milk yield (AMY): $487 \mathrm{~kg}$ ]. These animals mobilized much of their body reserves to sustain their milk yield at the expense of fertility [the pregnancy rate (PR) during current lactation was 64\%]. The three other profiles corresponded to cows with a lower milk yield and contrasted reproduction performance (Figure 2). Cows in profile two ( $n=111$; AMY: $320 \mathrm{~kg}$ ) mobilized body reserves but were able to maintain an acceptable PR at $71 \%$. Profile three $(n=67$; AMY: $331 \mathrm{~kg}$ ) corresponded to cows with a low body condition and high body reserve mobilization resulting in very thin animals at the start of the breeding period. Their fertility was thus very low (PR: $30 \%)$. Profile four ( $n=103$; AMY: $331 \mathrm{~kg})$ corresponded to cows with the most stable body condition score and the best fertility among all the profiles (PR: 92\%). Each profile 


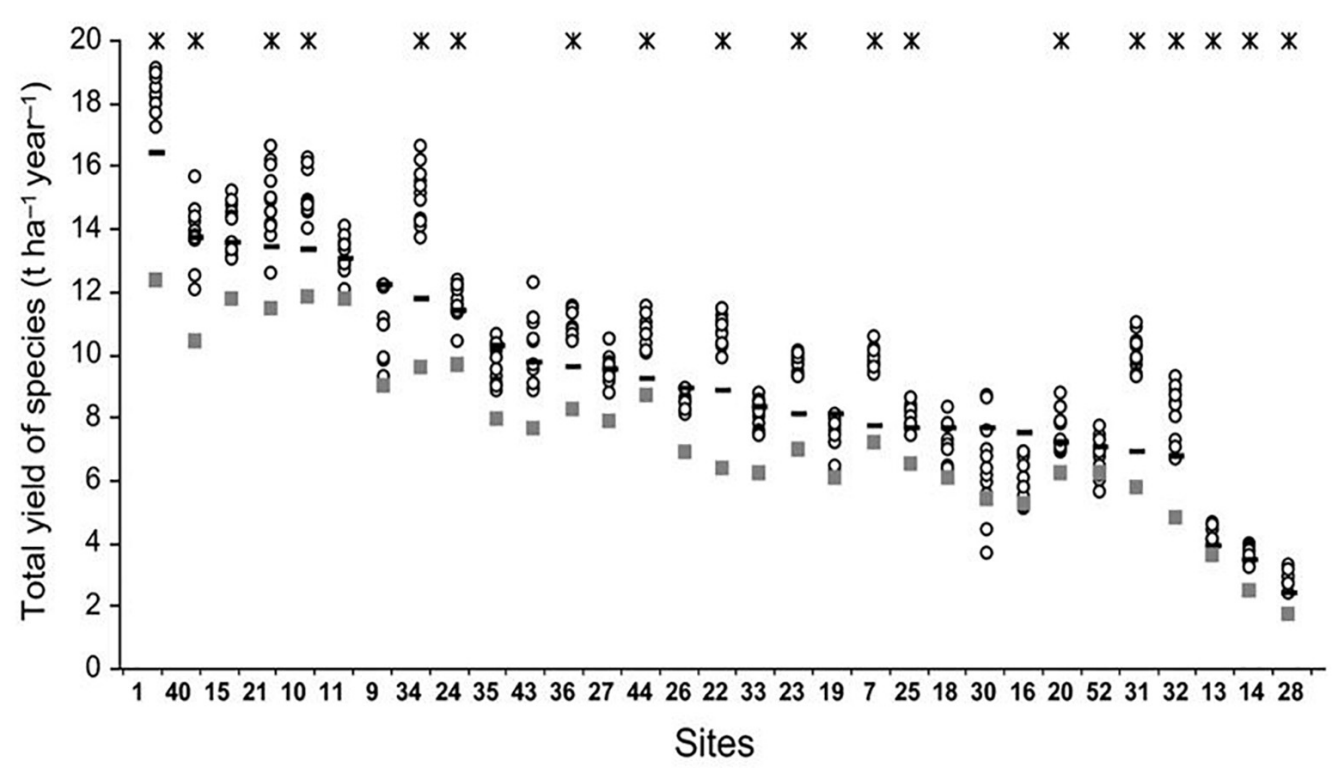

FIGURE 1 | Average annual total yield at each of 31 sites of a 3-years pan-European experiment in 17 countries testing whether higher yields, compared with monocultures, can be achieved with grass-legume mixtures containing four species [adapted from Finn et al. (2013)]. At each site open circles represent mixture yields, horizontal bar the yield of the best performing monoculture, gray square mean monoculture performance, and asterisk sites where mixture yields exceeded those of the best monoculture.

was linked to a specific adaptive response by the daily milk yield to perturbation, cows with profiles 2 and 4 showing no fluctuation (Figure 2). At herd level, the diversity of trade-offs and adaptive response of animals is assumed to buffer the effect of random environmental perturbations in the long term. This assumption was tested by Blanc et al. (2013) who simulated the annual milk yield produced by dairy herds composed of cows with either a single or different types of theoretical adaptive profiles (the ability to cope with feed shortages, heat stress or diseases). One simulated perturbation occurred every 3 years over a 50-year period and it was randomly related to either feed availability, heat or diseases. Simulation runs were repeated 50 times to account for the random effect of perturbation sequences. After 50-years, the results showed that while the annual milk yield was very stable across groups, the inter-annual variability was $25 \%$ less in the herd composed of cows with diverse adaptive profiles.

Beyond this modeling work, Magne et al. (2016) analyzed the productive performances of 22 multi-breed dairy herds from southern France and compared them with those of single-breed specialist (Holstein) or generalist (Montbeliarde or Simmental) herds from the same area. They concluded that multi-breed dairy herds experienced better trade-offs than singlebreed herds among milk yield, milk solids, herd reproduction and concentrate-conversion efficiency. However, experimental evidence that herd composition could be a factor in enhancing system resilience remains scarce, which highlights the need for more research on the technical and economic performances of varying the proportion of specialist and generalist individuals or breeds in mixed herds. Benefiting from this diversity requires the ability to adequately phenotype dairy cows to characterize their trade-offs between life functions and identify their response profiles to perturbations (Friggens et al., 2017).

Some effects of the genetic structure of animal groups are also expected in pigs, poultry, and rabbits, where genetic variability is usually 'concentrated' at the individual level (Figure 3). Purebred, specialized paternal, and maternal lines are crossed to produce the animals found in most commercial farms (Phocas et al., 2016). This organization allows the valorization of the complementarity between lines. It benefits from heterosis and leads to a homogeneous population of highly productive individuals. In sire lines, selection focuses on improving feeduse efficiency and increasing growth rate and carcass lean meat content (muscle depth), while accounting for the meat technological quality, for instance in boars. In maternal lines, the priority is to increase prolificacy (i.e., the number of young alive at parturition) while accounting for maternal abilities, for instance in sows (Phocas et al., 2016). Breed-related resistance to diseases (e.g., to swine fever) is also known in pigs (Depner et al., 1997), stressing opportunities offered by using the available genetic material in a combined and more rational way. Group diversity is assumed to limit the use of chemical drugs and animal mortality (Hamilton et al., 1990; Pekkala et al., 2014). In the case of intensive rabbit production, disease occurrence is a major challenge. Increasing herd genetic diversity by crossing specialized lines or raising lines from distinct genetic 

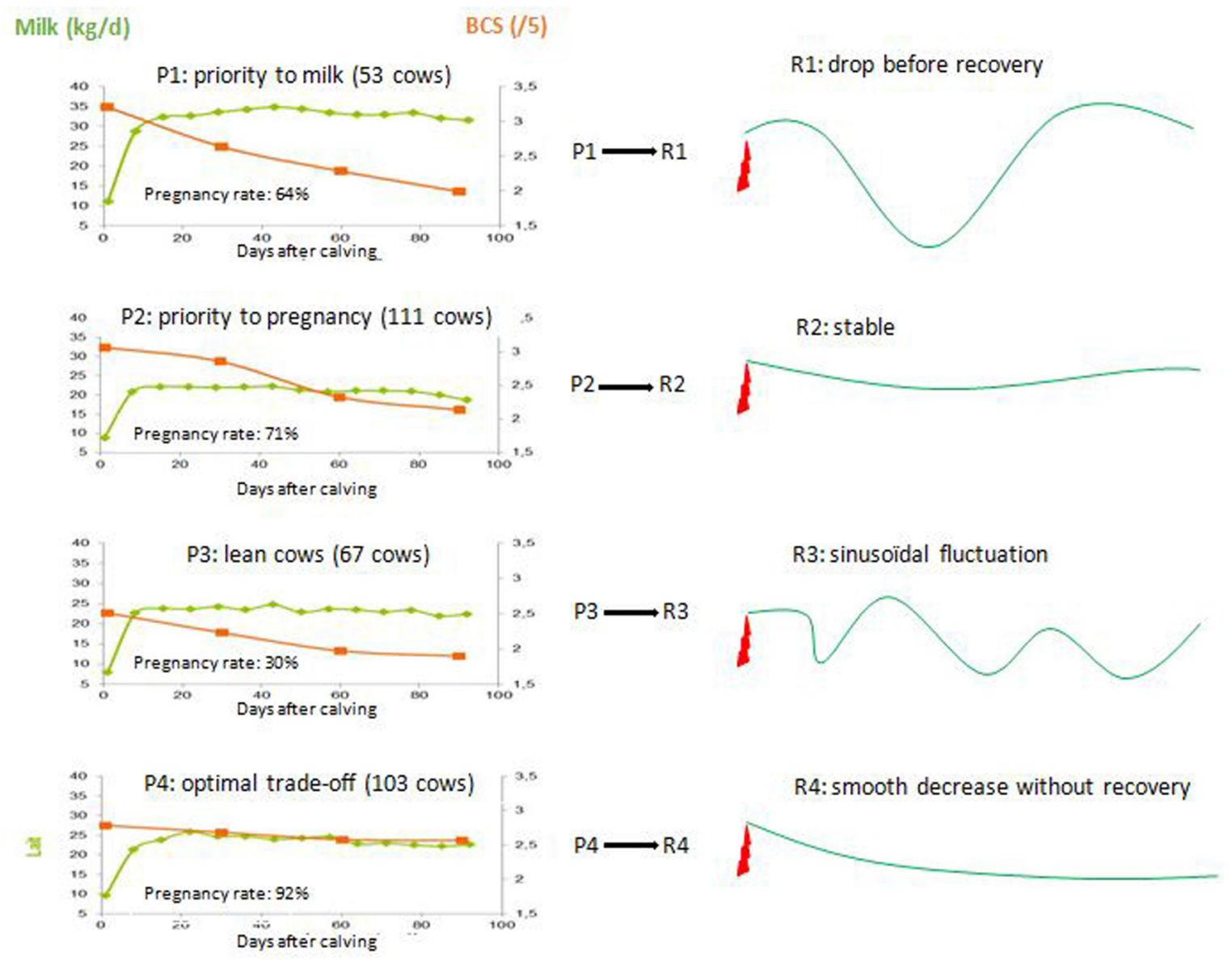

FIGURE 2 | Relationships between four individual trade-off profiles (P1-4 accounting for daily milk yield in green, body condition score in orange, and pregnancy rate during current lactation) of dairy cows measured in early lactation when competition between the functions is the highest, with their milk yield response (R1-4) to a perturbation (adapted from Ollion et al., 2016).

backgrounds together is assumed to provide benefits in terms of not only the complementarity of productive and adaptive traits from different lines and heterosis but also the herd and social immunity. While herd immunity refers to a reduction in disease transmission as the number of susceptible individuals in a population decreases (Fine, 1993) social immunity goes beyond that definition. It encompasses any type of immunity services provided by one individual to the others (Cotter and Kilner, 2010), such as the transmission of immunoglobulins via lactation, or self and collective grooming behavior. The results of a series of experiments conducted on rabbit lines affected by a rapidly spreading pathogen called epizootic rabbit enteropathy are demonstrative of herd immunity. In studying the effect of eight weaning diets on the health of rabbits from a unique crossbred line, Martínez-Vallespín et al. (2011) reported a mean mortality rate of $54.6 \%( \pm 15.4 \%)$. The post-weaning mortality was reduced to $16.5 \%( \pm 6.4 \%)$ (Savietto et al., 2012) and to $8.7 \%( \pm 5.5 \%)$ (García-Quirós et al., 2014) within a mixed-breed population of three genotypes. In this last experiment, one of the genotypes was a long-lived and productive line in which post-weaning mortality was as low as $3.6 \%$. These results suggest that beyond genetic susceptibility to diseases, the increase in genetic diversity at the herd level matters.

\section{VALUING INTERACTIONS AMONG SYSTEM COMPONENTS}

\section{Combining Plant and Animal Production}

Interactions between system components primarily refer to how context-appropriate combinations of plant and animal production could increase farm-scale productivity and resourceuse efficiency. For instance, in a network of 66 beef cattle farms of the Charolais area, organic farmers who grow crops on farms to feed cattle and efficiently exploit the diversity of feed resources had good technical performances (e.g., the highest percentage of calves weaned per cow service), and the lowest GHG emissions and non-renewable energy consumption per hectare (Veysset et al., 2014). Conversely, conventional mixed crop-livestock farmers that sell both meat and cereals were, on average, less efficient than the specialized grassland-based farmers. This example reveals that farm-scale diversity is not 


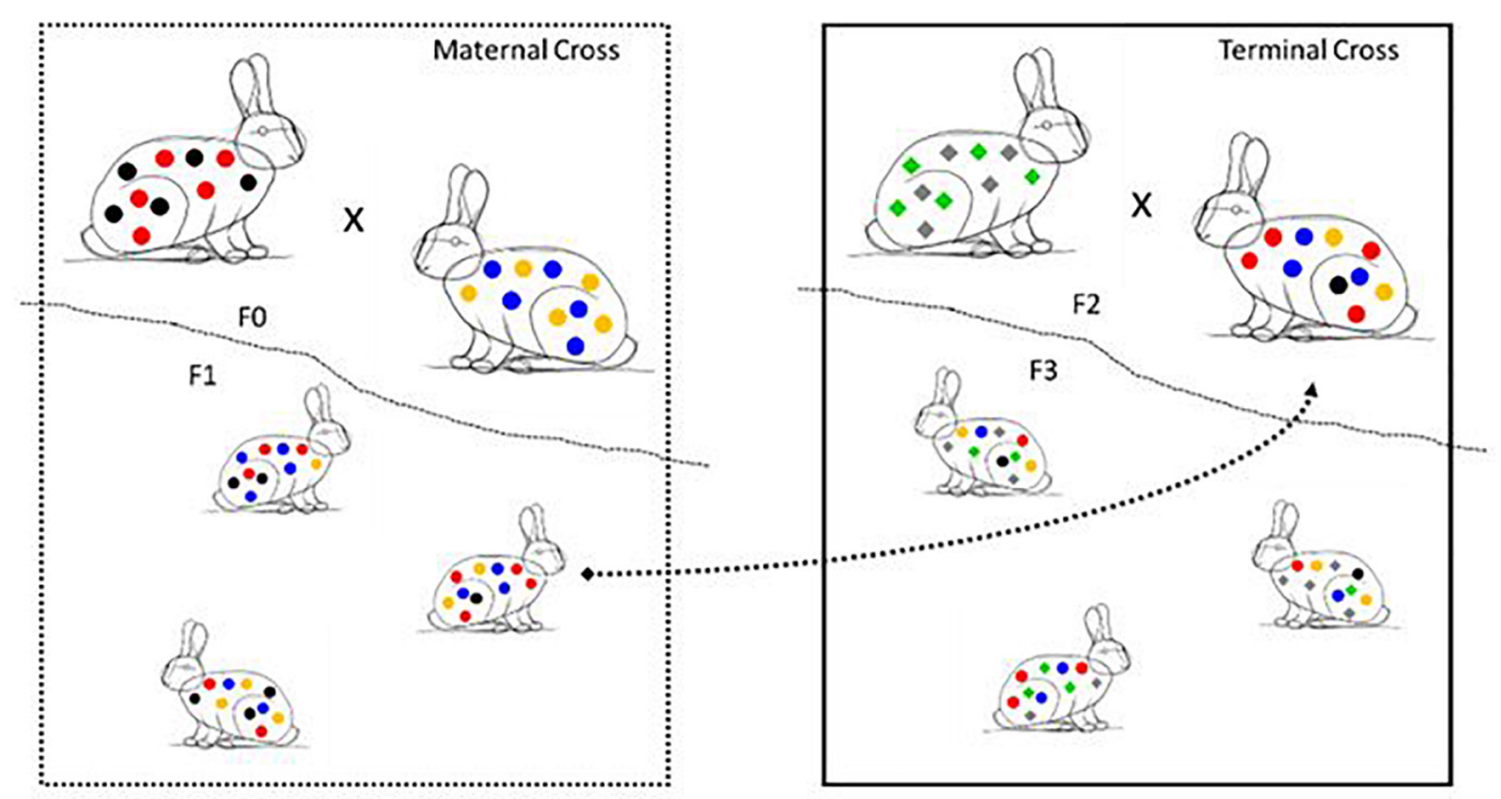

FIGURE 3 | Schematic representation of crossing specialized maternal lines (generation F0) for further crossing with a paternal line (generation F2). Genetic diversity is represented by colored shapes (circles for maternal lines and diamonds for the paternal line).

sufficient to increase resource-use efficiency and that interactions between components of APSs are needed.

There are some other demonstrations of the benefits of resource diversification on farm self-sufficiency, environmental performance and farm resilience in ruminant systems. In Australia, increasing the length of the alfalfa phase in the rotation decreased the variability in production and ecosystem services value (Kragt and Robertson, 2014). This is because annual crops display more inter-annual variation in production due to variations in timing and amount of rainfall than perennial pastures. Another farm-scale simulation analyzed the forage autonomy of four dairy farms located on a NW-SE diagonal across France over a succession of 4 years and under varying weather conditions (Martin and Magne, 2015). A change in the variety of and balance between crops and grasslands grown on the farms was shown to promote redundancy in forage resources and to buffer year-to-year variations in forage yields. Crop diversification increased the self-sufficiency for forage and resilience of dairy farms after two unfavorable years, while changing the calving period only had a minor additional effect. There are benefits of grazing cover crops in rotation with cash crops for primary and secondary production and for soil physical, chemical, and biological parameters (Carvalho et al., 2018). However, careful management of grazing intensity is needed as overgrazing can lead to soil deterioration. In organic farms, crop rotations are $15 \%$ longer than those in conventional systems and result in higher diversity and more even crop species distributions (Barbieri et al., 2017). These changes are largely driven by a higher abundance of temporary fodders and cover crops. Indeed, several legume or non-legume cover crops have a high nutritive value for ruminants and provide ecosystem services, such as soil fertility and weed control. Some of them also have the potential to decrease GHG emissions by the animals (Maxin et al., 2020). In silvopastoral systems, trees buffer crops and grasslands from large fluctuations in temperature, reduce soil evaporation and increase soil water infiltration. Farms with several vegetation strata, including trees, showed buffered forage yields in cases of severe droughts and an $80-90 \%$ productivity recovery 40 days after a hurricane (Altieri et al., 2015). There could thus be a wide range of conditions under which multispecies plant communities represent an efficient adaptation strategy against climatic events. An important challenge will be the development of innovative forage systems that intercrop plant species at different strata in temperate areas, notably in agroforestry systems, which are perceived by stakeholders to improve not only the environmental performance of livestock farming systems but also animal health and welfare (García de Jalón et al., 2018).

\section{Multi-Species Animal Production Systems}

The higher performance of multi-species APSs is assumed to result from (i) the complementary feeding habits of animal species that exploit trophic resources from different ecological niches more efficiently and (ii) facilitation or competitive exclusion, which results in an animal species increasing or decreasing the resource availability for another species. Aquaculture is a good illustration of these ideas, as manipulating combinations of species of carps and small indigenous fish enhances fish production in the polyculture systems of southern or South-eastern Asia (Milstein, 2005; Milstein et al., 2006; Wahab et al., 2011). This performance largely results from differences in the feeding strategies of fish species that are mixed, for instance, a combination of filter, herbivorous, and bottom 
feeders (Milstein, 2005 Figure 4). Mixing species that exploit the same resource at different times and/or in different spaces (so that they do not compete directly) can lead to the same benefit. For instance, farming sterlets (Acipenser ruthenus) with juvenile pikeperch (Sander lucioperca) in a recirculating aquaculture system increases the feed-use efficiency and reduces the labor needed for tank maintenance (Kozlowski et al., 2014). This efficiency occurs because the pikeperch consume feed floating in the water column, while the sterlets feed on the food that sinks to the bottom. One species can even enhance the food availability for another species through the facilitation process. For instance, Milstein et al. (2006) found a 50\% increase in biomass production and a higher growth rate of rohu (Labeo rohita) when they are raised with common carp (Cyprinus carpio), a bottom-feeder, because common carp improve the nutrient re-circulation in the water column through the bioturbation of sediments when feeding on benthic organisms. The physical movement of the sediments favors phytoplankton development and thus increases the feed resources available in the water column where the rohu feed. Finally, differences in fish adaptive profiles can buffer a pond ecosystem, such as when local fish species reared in polyculture systems in Mexico were able to resist hypoxia and desiccation under conditions that caused massive mortality of carp (Moctezuma-Malagón et al., 2008).

There are thus strong analogies to what is observed in grassland-based systems, in which a combination of livestock species with complementary ecological niches also increases the overall use of pastures. The results of a meta-analysis reveal a positive effect of mixed grazing of sheep and cattle on the daily live weight gain of sheep, while cattle live weight gain was similar in mixed and monospecific grazing systems. On average, sheep grazed with cows grew $14.5 \mathrm{~g}$ /day faster than those grazed alone, resulting in higher meat production per hectare compared with that of a monospecific grazing system (d'Alexis et al., 2014). In another survey conducted over 5 years on permanent grasslands in Germany, lamb production also showed the highest benefits under mixed grazing, with a $17 \%$ increase in liveweight gain (Jerrentrup et al., 2020). Mixed grazing significantly increased daily average liveweight gains of suckler cows, but not that of calves. Mixed system productivity was also higher, which confirms the advantages of combining livestock species, attributed to complementary pasture use. This complementarity between grazing species could, however, lead to overgrazing as observed across nine Uruguayan farms where sheep to cow ratio was negatively correlated with cow pregnancy rate (Modernel et al., 2019). Due to their nutritional requirements and morphological capacities, cattle and sheep exhibit distinct grazing behaviors (Dumont et al., 1995) and have complementary effects on the vegetation structure, which can benefit pasture nutritive value (Jerrentrup et al., 2020) and biodiversity. For instance, mixed grazing with sheep and cattle not only improved livestock production but also provided

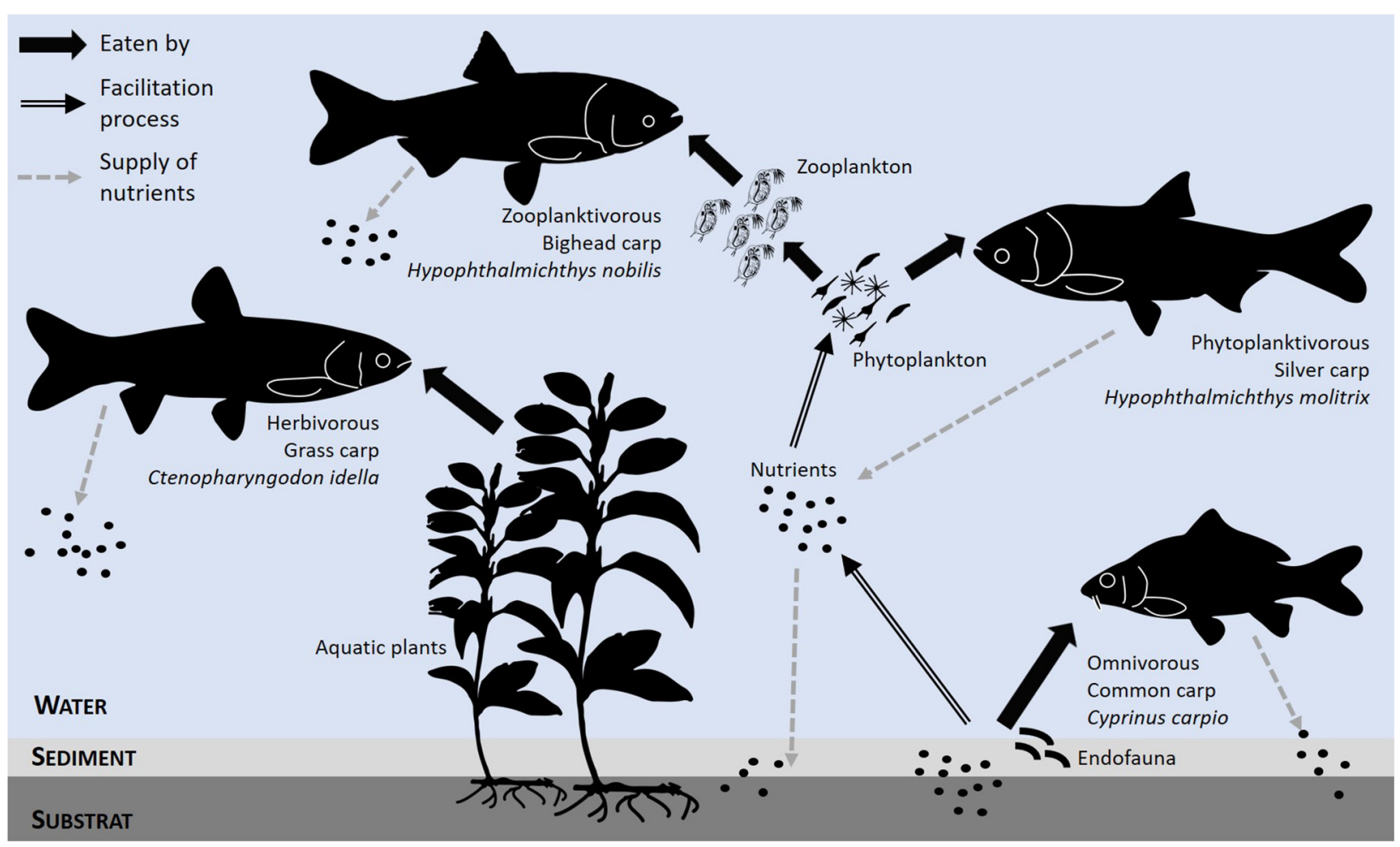

FIGURE 4 | An example of manipulation of the trophic network in the polyculture of cyprinidae, with two objectives: (i) the trophic complementarity of fish species, leading to an effective use of available food resources, and (ii) the exploitation of the facilitation process occurring through the bioturbation of sediments that promotes plankton development on which other fish species rely [adapted from Milstein (2005)]. 
suitable habitats for butterflies in Welsh upland pastures (Fraser et al., 2014). A recent study extended this finding across six groups of above-ground and below-ground organisms (plants, herbivorous insects, predatory insects, soil bacteria, fungi, and nematodes), and it suggested that mixed grazing is likely to provide enhanced levels of ecosystem services (Wang et al., 2019). Thanks to their two sets of incisors, horses graze close to the ground and maintain relatively stable open patches with specific plant communities (Ménard et al., 2002; Fleurance et al., 2016). Patch stability is likely to impact ecosystem functioning for agricultural (maintaining sward nutritive value) or conservation purposes (Dumont et al., 2012). Another key process is the competitive exclusion of cattle by horses: as cattle were not able to meet their daily requirements on the short lawns they switched to tall grass areas where they limited the development of competitive and unpalatable grasses on horse latrine areas. Consequently, co-grazing cattle and horses produced more species-rich vegetation communities than cattle or horses grazing alone (Loucougaray et al., 2004). Species combinations between ruminants and monogastrics (e.g., cattle and pigs or poultry) remain largely ignored, although they may have some potential due to their complementary diet compositions and resourceacquisition strategies (Sehested et al., 2004; Martin et al., 2020).

Polyculture fish production systems and mixed grazing systems can also achieve higher performance as a result of processes that benefit animal health. These benefits can be direct or indirect. An example of a direct effect comes from salmon farms, in which some fishes (e.g., wrasses and lumpsuckers), named 'cleaner fishes', benefit Atlantic salmon by removing ectoparasites, such as sea lice (Skiftesvik et al., 2013). In polyculture systems, a small proportion of carnivorous fishes can also contribute to the system performance by feeding preferentially on weak and ill individuals, thus limiting the pathogen load and diffusion. Such system could, however, be considered unacceptable from an animal welfare point of view. Some observations suggest that mixed grazing of pastures may directly reduce predation risks in poultry when grazed with cattle (Martin et al., 2020) or sheep, e.g., when grazed with donkeys or llamas in traditional pastoral systems (Smith et al., 2000). An indirect effect is the control of gastrointestinal parasites on pastures grazed by several herbivore species as the result of a dilution effect. Most nematode species exhibit high specificity for their hosts and are unable to complete their lifecycle when swallowed by a non-susceptible species. Mixed grazing, thus, appears to be an efficient strategy for reducing nematode infection in small ruminants (Marley et al., 2006; Mahieu, 2013) and young saddle horses (Forteau et al., 2020). This dilution effect is likely to decrease treatment frequency, and thus drug resistance, veterinary costs and environmental side effects of drug metabolites on dung beetle assemblages (Sands and Wall, 2018). The various benefits of mixing different animal species on the same farm should not overshadow the health hazards that they can induce and that need to be carefully evaluated. Cross species transmissions have been reported for bacterial diseases between co-grazing sheep and cattle (Moloney and Whittington, 2008; Rodgo et al., 2012). Another example in more intensive systems comes from the observation that some infectious agents, such as influenza viruses, can adapt to different species, increase their virulence after recombination and even be transmitted from animal reservoirs to humans (Kuiken et al., 2006).

\section{MANAGING FOR RESILIENCE: DIVERSITY ALLOWS FOR ADAPTING TO RISKS AND UNCERTAINTIES}

\section{Is Resilience a Manageable Property of Animal Production Systems?}

The first two sections of this paper have shown the extent to which valuing diversity of system components and interactions among them can increase the performance patterns of APSs (especially their productivity and resource-use efficiency) and strengthen their resilience, mainly via more stable production and reduced sensitivity to hazards (e.g., diseases). Such expected benefits depend on the implementation of finetuned management practices in time and space to take advantage of underlying ecological mechanisms, such as niche complementarity and facilitation. Otherwise, trade-offs may occur among organizational levels and between system performance patterns (e.g., productivity and efficiency) and system resilience (Peterson et al., 2018). This raises the question of how to manage resilience in APSs.

The buffer, adaptive and transformative capabilities of any resilient system (Darnhofer, 2014) refer to different types of management decisions. Buffer capability involves strategic decisions at the current farm configuration stage. Such decisions apply both when defining the level of within-farm diversity (e.g., sowing multispecies pastures or using different breeds in mixed herds) and when planning interactions among system components (e.g., co-grazing or feeding animals with crop residues; Table 1). Adaptive capability involves tactical decisions aimed at adjusting to hazards and changes. It is not always easy to modify the level of within-farm diversity in the course of a year, but interactions among system components can be revised and combined with other components (e.g., selling animals to reduce stocking density) to mitigate the effects of hazards and changes. Transformative capability involves strategic decisions and implies a transition to a new system. It involves a full reconfiguration of the farm layout, e.g., introducing aquaculture into existing integrated farming systems (Dumont et al., 2013), which drastically modifies both the level of within-farm diversity and the interactions among the system components.

Consistently managing these three capabilities remains a challenge. This partly relates to our limited knowledge of how management options nested in the APS diversity can enhance system resilience beyond the buffering capability discussed in the two previous sections. It is likely that managing for resilience based on the within-farm diversity of APSs will result in a greater management complexity for the farmer (Kingwell, 2011; Dumont et al., 2013) and require additional technical skills, for instance, for managing a new livestock species. García de Jalón et al. (2018) reported that increased complexity of work, management costs 
TABLE 1 | A typology of resilience factors [according to Darnhofer (2014)] related to on-farm diversity with examples.

\begin{tabular}{|c|c|c|c|}
\hline & Feed resource & Animal & Farm management \\
\hline Buffer capability & $\begin{array}{l}\text { - Sow multispecies swards. } \\
\text { - Keep a diversity of permanent } \\
\text { pastures. } \\
\text { - Sow temporary fodders and cover } \\
\text { crops in crop rotations. }\end{array}$ & $\begin{array}{l}\text { - Use different breeds/lines in mixed } \\
\text { herds. } \\
\text { - Breed fish species with different } \\
\text { ecological niches. }\end{array}$ & $\begin{array}{l}\text { - Graze different livestock species on the same plots. } \\
\text { - Increase crop-livestock interactions, i.e., use crop } \\
\text { residues to feed animals and manure to fertilize crops. }\end{array}$ \\
\hline Adaptive capability & $\begin{array}{l}\text { - Use dual purpose crops. } \\
\text { - Use tree foliage (e.g., Fraxinus } \\
\text { excelsior L.) to feed animals. }\end{array}$ & - Lengthen animal productive lifespan. & $\begin{array}{l}\text { - Sell animals to reduce stocking density. } \\
\text { - Adapt the type of product sold to market conditions. } \\
\text { - Modify equilibrium between herds in multispecies farms. }\end{array}$ \\
\hline $\begin{array}{l}\text { Transformative } \\
\text { capability }\end{array}$ & $\begin{array}{l}\text { - Exchange feeds, straw and manure } \\
\text { with local specialized crop farmers. }\end{array}$ & - Graze animals on cover crops. & $\begin{array}{l}\text { - Introduce aquaculture into existing integrated farming } \\
\text { systems. } \\
\text { - Add pigs/poultry (short production cycles) to cattle farms } \\
\text { to achieve more regular cash inflows. } \\
\text { - Develop a processing enterprise (e.g., sausages) and } \\
\text { sales on farm. } \\
\text { - Develop agritourism. }\end{array}$ \\
\hline
\end{tabular}

and administrative burden were the most limiting factors for the transition to agroforestry systems.

Additionally, despite several scientific indicator frameworks (Cabell and Oelofse, 2012; Speranza et al., 2014) farmers lack simple and reliable indicators to monitor the resilience of their farms over time and relate it to the implemented adaptations and/or transformations (Peterson et al., 2018). Two types of indicators are needed. Indicators relying on "fast" variables, e.g., the presence of parasites in animal dung (Forteau et al., 2020) and stocked biomass in pastures (Do Carmo et al., 2016), are of interest to farmers for managing hazards in the course of a year (Walker et al., 2012). The dynamics of these fast variables are dependent on other system variables that change much more slowly, e.g., soil nitrogen availability and soil organic matter content (Wang et al., 2019) and are therefore referred to as "slow" variables (Walker et al., 2012). These slow variables are excellent indicators of the medium- to long-term resilience of farms.

\section{Promoting Buffer Capability via the Management of APS Diversity}

Buffer capability is sometimes referred to as robustness or resistance in the literature (de Goede et al., 2013). It can be enhanced by planning within-farm diversity, which can in turn improve farmer profit (Table 1). For instance, replacing ryegrassclover mixtures with multispecies pastures, including species such as chicory and alfalfa, increased profit in New Zealand dairy farms due to the increased biomass harvested on the farms. Nitrate leaching also decreased from 61 to $34 \mathrm{~kg} \mathrm{~N} /$ ha, indicating that multispecies swards can be a cost-effective way to reduce nitrogen leaching and achieve win-win options for grazing systems in terms of economic and environmental performance (Romera et al., 2017). Related to animal management, Diakité et al. (2019) assessed the profit stability of mixed dairy and beef cattle farms compared to that of specialized farms against variations in milk and meat prices. These authors simulated mixed farms and specialized cattle farms (dairy or beef) in the upland Auvergne area (France), while accounting for pasture agronomic potential, field configurations and animal productivity. The model outputs revealed that mixed cattle farming would be an effective strategy to manage market risks, as it provides a good balance between higher annual net profit and less variability in net profit (Figure 5). As discussed in the previous section, grazing different animal species on the same plots offers various levers to increase the buffer capability of multi-species APSs. Co-grazing cattle and sheep has also been shown to improve the abundance and diversity of six groups of above-ground and below-ground organisms (plants, herbivorous insects, predatory insects, soil bacteria, fungi, and nematodes; Wang et al., 2019). This confirms that APS diversity is a key aspect to consider in system design in order to come to win-wins balancing productive and environmental goals.

Buffer capability can also be promoted by planning interactions among system components. Sneessens et al. (2019) analyzed the economic results of 208 French croplivestock farms over a 14-year period. Farms that were more diverse and had more crop-livestock interactions had higher and less variable annual income. They experienced fewer economic disruptions and required less time to recover after a disruption. Farmers promoting interactions among crop and livestock components within a farm had lower expenses in terms of energy per hectare, water per hectare, and feed concentrate consumption per animal, thereby displaying better environmental performance patterns. In the beef-farm network of the Charolais area, the higher resource-use efficiency of organic beef farmers that fed their cattle with grasslands, grain produced on-farm and crop residues decreased production costs by $30-35 \%$ and increased the net-income per worker by $20 \%$ (Veysset et al., 2014). Such a reduction in market dependency via increased self-sufficiency and high resourceuse efficiency was also reported in Mediterranean pastoral systems (Bernues et al., 2011) and in organic dairy cattle farms (Perrin et al., 2020).

Although APS diversity and interactions among system components are needed to promote system buffer capability and enhance farmer profit and economic-environmental tradeoffs, there is a theoretical diversity optimum beyond which 
system resilience would be compromised by the level of APS diversity and interactions (Figure 6). Biggs et al. (2012) suggested that though low levels of diversity limit options for adapting to change, high levels of diversity in interconnected farming systems would be too complex to manage due to an inability to integrate all the possibilities and parameters into an analysis, leading to system stagnation. Social lock-ins occurring at the implementation stage can thus compromise the achievement of better trade-offs among economic and environmental performance expected at the farming design stage.

\section{Promoting Adaptive Capability via the Management of APS Diversity}

Adaptive capability is sometimes referred to as flexibility (Astigarraga and Ingrand, 2011; Nozières et al., 2011) in the

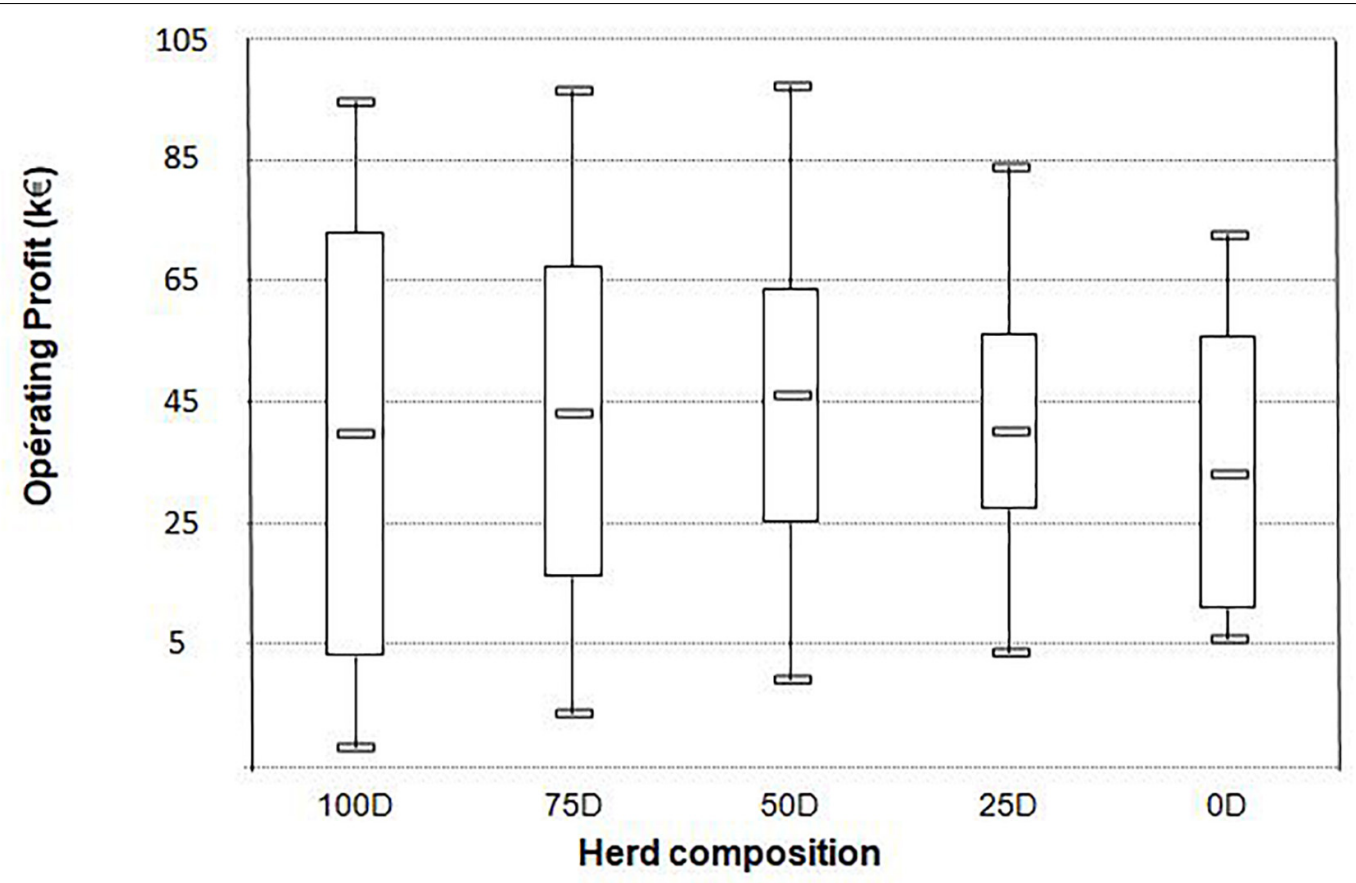

FIGURE 5 | Boxplots of net profit from 27 simulations in scenarios of a mixed dairy-beef farm in French Massif central, in which prices of milk, beef, and concentrate feed varied simultaneously among three levels [adapted from Diakité et al. (2019)]. D represents the relative proportions of dairy cows, so that 75D is a 75-25\% dairy-beef combination. Net profit was on average higher in the 50-50\% dairy-beef combination (50D), while profit variability was the lesser in the $25-75 \%$ dairy-beef combination (25D).

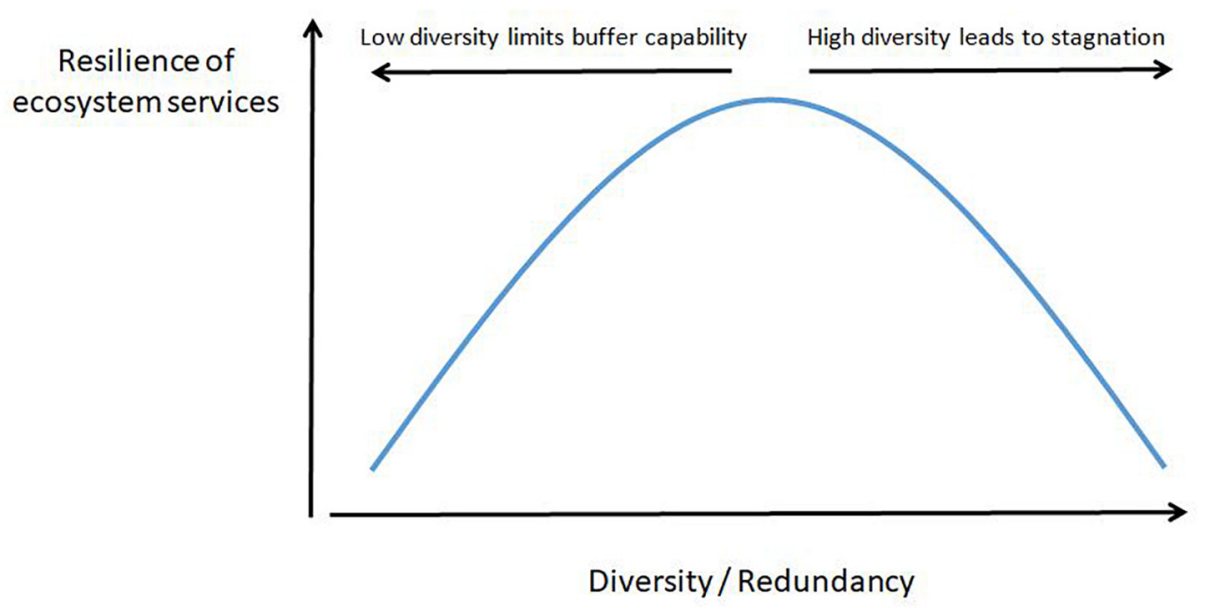

FIGURE 6 | Theoretical relationship between system diversity/redundancy and the resilience of ecosystem services [adapted from Biggs et al. (2012)]. The shape of this curves suggests an optimum beyond which system resilience would be compromised by the level of APS diversity and interactions. 
literature and could be promoted by within-farm diversity. When focusing on the pasture and crop component, dual purpose crops (Table 1) can be used by farmers to adapt to the conditions of a specific year. This practice consists of grazing the crop during the early vegetative stages and harvesting grain at maturity. The use of dual-purpose crops has a limited impact on yield $(-7 \pm 25 \%$ across 270 experiments; Harrison et al., 2011) and avoids using extra area to feed livestock, thereby limiting feedfood competition and the environmental footprint of livestock farming. In the case of a feed shortage, it is also possible to feed ruminants tree foliage [e.g., from ash (Fraxinus excelsior L.) in temperate areas or Leucaena leucocephala in the tropics] as part of their daily diet, with similar environmental side-effects than dual-purpose crops.

When focusing on the animal component, farmers can lengthen the animal productivity lifespan (thus enhancing diversity in animal age classes) and thus increase production efficiency, as the proportion of the animal lifespan during which it is non-productive is proportionally lower. At the farm scale, it is also possible to adapt the type of product sold to the market conditions. For instance, in Limousin, France, calves can be sold as lean male calves just after weaning or as young heifers for fattening, fattened heifers or as reproductive females (Astigarraga and Ingrand, 2011). Selling animals to decrease stocking density is a classical way to adapt to unfavorable grass growth (Table 1). In Uruguayan grasslands, decreasing beef farm stocking density was shown to increase farm technical and economic performances and alleviate the effects of climatic variability (Do Carmo et al., 2016) thus increasing farm resilience. In multi-species herbivore systems, the breeder can also adapt to climatic shocks or price fluctuations in the short and medium term by juggling the relative weights of the two herds (Nozières et al., 2011). After considerable herd mortality, adaptive capability consists of selling part of the resistant, slow-growing species that survived to buy animals from less resistant but fast-growing species. For instance, Mongolian herders temporarily replace their camels and horses by goats after substantial winter die-offs (Joly et al., 2019). Similar traitbased exchange strategies involving camels and small ruminants are used in sub-Saharan Africa to mitigate the effects of severe droughts (Mace, 1990).

\section{Promoting Transformative Capability via the Management of APS Diversity}

Transformative capability can also be promoted by enhancing within-farm diversity. Hansson et al. (2010) described two ways to transform a farm through diversification toward enhanced resilience: either by adding a new activity (fattening, adding a new species, etc.) within conventional APS or by developing a para-agricultural activity using the farm's resources, such as a processing enterprise (farm-made cheese, processing pork into sausages, etc.) or agritourism (Table 1). López-i-Gelats et al. (2011) reported these two farm trajectories in the Pyrenees with some farms relying on agricultural diversification (via the management of APS diversity) and others implementing farmland diversification (i.e., the shift away from the production of food to exploit the multifunctional nature of agriculture, e.g., through agritourism). They also identified a further level of diversification, labor diversification, which relates to the shift from family labor toward off-farm employment.

According to Chavas (2008) diversification of APS could generate two forms of benefits that could strengthen farm resilience: 'the presence of economies of scope, reflecting the reduced cost associated with producing multiple outputs, and the risk-reducing effects of diversification.' However, we still lack evidence of the economic benefits of transformative farm diversification, especially from a resilience perspective. For instance, in the Charolais area, conventional mixed croplivestock farmers who sell both meat and cereals seemed unable to take advantage of economies of scope due to the lack of interactions between the crop and beef components of their systems (Veysset et al., 2014). This may relate to the abovementioned social lock-ins especially management complexity. The risk-reducing effect of transformative diversification was, however, mentioned by Valenti et al. (2018) as a factor of resilience in aquaculture. In a multispecies livestock system, adding pigs or poultry, which have a short production cycle, to a beef or dairy cattle system (i.e., a long production cycle) could lead to more regular cash inflows and more stable incomes thereby indirectly enhancing farm resilience (Table 1). Together with a reliance on different global markets (i.e., pork and milk/dairy), such a transformative diversification of APS is assumed to stabilize farm financial situations and can thus be seen as part of the securitization strategy of farmers. In multispecies livestock systems, pork and poultry, for which there is a high consumer demand across Europe (Centner, 2019; Rauw et al., 2020) could be used as call-products to attract and retain local customers; this again enhances farm resilience. It was thus recently shown that there is a demand among consumers from central France for beef-pork-vegetable 'baskets', which benefits the commercialization of local beef products (Vollet and Said, 2018). Having a diversified range of products for sale also facilitates the use of short supply channels and may contribute to enhancing customers' interest in local products. However, meat processing on-farm usually requires a major initial investment. Developing a new production line can also lead to the need to hire new farm workers, as introducing a new livestock species to a farm requires additional technical skills. These investments imply taking a financial risk and may thus prevent farm diversification, and its positive effects on resilience. Still some of these transformative diversification pathways are welldocumented. For instance, combining pig and cattle production (mainly dairy cattle) at the farm level is common in France, where $38 \%$ of pig farms (corresponding to $27 \%$ of pork production) are associated with ruminants (Dourmad et al., 2018).

\section{CONCLUSION}

In this paper, we have discussed examples from various types of APSs, including aquaculture, rabbit, monogastric, and ruminant systems. In addition to theoretical developments, evidence reveals that the benefits of diversity are grounded in the 
inter-individual, inter-breed or inter-specific variability in response to environmental conditions. The benefits of diversity were observed not only in relatively extensive systems but also in intensive indoor systems for fish, rabbit, and dairy production. Therefore, the level of system intensification does not seem to prevent the use of inter-individual diversity as a driver for resource-use efficiency and farm resilience. This, however, requires that animals are phenotyped to capture the tradeoffs between their life functions and to describe their adaptive capacities. The benefits of diversity also arise from a network of interactions generating emergent properties at the farming system level. Management practices can modulate the scale and direction of interactions among plants and animals or among animal components so that synergies occur.

These findings allow us to define a number of research priorities. It is still necessary to address the empirical evidence on the linkages between APS diversity and resilience under a larger range of conditions. This involves monitoring system resilience based on long-term farm surveys and the prioritization of individual life functions throughout animal productive lifespans, e.g., across all subsequent lactation cycles. This could be achieved through the coordinated use of European ${ }^{1}$ or global research infrastructures. To ensure general insights, a common set of indicators across a range of experimental or commercial farms still needs to be defined, together with a standardized description of APSs, especially their diversity and the perturbations they face. Once this indicator issue has been solved (and more data are available), a research avenue will be to carry out a meta-analysis of the effects of diversity on farm performance and resilience. Simulation modeling could also allow extrapolation of the findings from these surveys and

${ }^{1}$ https://www.smartcow.eu/

\section{REFERENCES}

Altieri, M. A., Nicholls, C. I., Henao, A., and Lana, M. (2015). Agroecology and the design of climate change-resilient farming systems. Agron. Sustain. Dev. 35, 869-890. doi: 10.1007/s13593-015-0285-2

Astigarraga, L., and Ingrand, S. (2011). Production flexibility in extensive breed farming systems. Ecol. Soc. 16:7.

Barbieri, P., Pellerin, S., and Nesme, T. (2017). Comparing crop rotations between organic and conventional farming. Sci. Rep. 7:13761. doi: 10.1038/s41598-01714271-6

Bernues, A., Ruiz, R., Olaizola, A., Villalba, D., and Casasús, I. (2011). Sustainability of pasture-based livestock farming systems in the European Mediterranean context: synergies and trade-offs. Livest. Sci. 139, 44-57. doi: 10.1016/j.livsci. 2011.03.018

Biggs, R., Schlüter, M., Biggs, D., Bohensky, E. L., Burn Silver, S., Cundill, G., et al. (2012). Towards principles for enhancing the resilience of ecosystem services. Annu. Rev. Environ. Resour. 37, 421-448.

Blanc, F., Ollion, E., Puillet, L., Delaby, L., Ingrand, S., Tichit, M., et al. (2013). Evaluation quantitative de la robustesse des animaux et du troupeau : quels principes retenir ? Renc. Rech. Rumin. 20, 265-272.

Bommarco, R., Kleijn, D., and Potts, S. G. (2013). Ecological intensification: harnessing ecosystem services for food security. Trends Ecol. Evol. 28, 230-238. doi: $10.1016 /$ j.tree.2012.10.012

Cabell, J. F., and Oelofse, M. (2012). An indicator framework for assessing agroecosystem resilience. Ecol. Soc. 17:18. doi: 10.5751/ES-04666-170118 experiments by directly exploring the strength, direction, and synergic effects of inter-individual, inter-breed, inter-specific, and crop-livestock interactions. A further step will be to include the knowledge of the linkages between APS diversity and resilience into co-designed approaches. These can be used to guide farmers toward adaptive or transformative changes, leading to the increased use of the potentialities of APS diversity.

\section{AUTHOR CONTRIBUTIONS}

BD led the writing and revision process, with all co-authors agreeing on manuscript structure, contributing to manuscript development, and reviewing the final version of the manuscript. All authors contributed to the article and approved the submitted version.

\section{FUNDING}

This position manuscript was initiated by INRAE Phase Division on Animal Husbandry and Livestock Farming Systems.

\section{ACKNOWLEDGMENTS}

We are grateful to Frédéric Joly, Bénédicte Lebret, and Claire Mosnier for helpful comments on a first draft of the manuscript. We also benefited from fruitful discussions with colleagues from PSDR4-Auvergne 2015-2020 project new-DEAL, and from the MIX-ENABLE project provided by transnational funding bodies, being partners of the H2020 ERA net project, CORE Organic Cofund, with the cofund from the European Commission.

Cardinale, B. J., Wright, J. P., Cadotte, M. W., Carroll, I. T., Hector, A., Srivastava, D. S., et al. (2007). Impacts of plant diversity on biomass production increase through time because of species complementarity. Proc. Natl. Acad. Sci. U.S.A. 104, 18123-18128. doi: 10.1073/pnas.0709069104

Carvalho, P. C. F., Peterson, C. A., de Albuquerque Nunes, P. A., Martins, A. P., de Souza Filho, W., Bertolazi, V. T., et al. (2018). Animal production and soil characteristics from integrated crop-livestock systems: towards sustainable intensification. J. Anim. Sci. 96, 3513-3525. doi: 10.1093/jas/sky085

Centner, T. J. (2019). Consumers, Meat and Animal Product. Policies, Regulation and Marketing. Oxon: Routledge Publishing.

Chavas, J. P. (2008). On the economics of agricultural production. Aust. J. Agric. Resour. Econ. 52, 365-380.

Collas, C., Sallé, G., Dumont, B., Cabaret, J., Cortet, J., Martin-Rosset, W., et al. (2018). Are sainfoin or protein supplements alternatives to control small strongyle infection in horses? Animal 12, 359-365. doi: 10.1017/ s1751731117001124

Cotter, S. C., and Kilner, R. M. (2010). Personal immunity versus social immunity. Behav. Ecol. 21, 663-668. doi: 10.1093/beheco/arq070

d'Alexis, S., Sauvant, D., and Boval, M. (2014). Mixed grazing systems of sheep and cattle to improve liveweight gain: a quantitative review. J. Agric. Sci. (Camb.) 152, 655-666. doi: 10.1017/s0021859613000622

Darnhofer, I. (2014). Resilience and why it matters for farm management. Eur. Rev. Agric. Econ. 41, 461-484. doi: 10.1093/erae/jbu012

de Goede, D. M., Gremmen, B., and Blom-Zandstra, M. (2013). Robust agriculture: balancing between vulnerability and stability. NJAS Wagen. J. Life Sci. 6, 1-7. doi: 10.1016/j.njas.2012.03.001 
Depner, K. R., Hinrichs, U., Bickhardt, K., Greiser-Wilke, I., Pohlenz, J., Moennig, V., et al. (1997). Influence of breed-related factors on the course of classical swine fever virus infection. Vet. Rec. 140, 506-507. doi: 10.1136/vr.140.19.506

Diakité, Z. R., Corson, M. S., Brunschwig, G., Baumont, R., and Mosnier, C. (2019). Profit stability of mixed dairy and beef production systems of the mountain area of southern Auvergne (France) in the face of price variations: bioeconomic simulation. Agric. Syst. 171, 126-134. doi: 10.1016/j.agsy.2019.01.012

Do Carmo, M., Claramunt, M., Carriquiry, M., and Soca, P. (2016). Animal energetics in extensive grazing systems: rationality and results of research models to improve energy efficiency of beef cow-calf grazing Campos systems. J. Anim. Sci. 94(Suppl.6), 84-92. doi: 10.2527/jas.2016-0596

Dourmad, J. Y., Salaün, Y., Lebret, B., and Riquet, J. (2018). Diversité des productions porcines en France. Innov. Agron. 68, 151-170.

Dumont, B., Fortun-Lamothe, L., Jouven, M., Thomas, M., and Tichit, M. (2013). Prospects from agroecology and industrial ecology for animal production in the 21st century. Animal 7, 1028-1043. doi: 10.1017/s1751731112002418

Dumont, B., Groot, J. C. J., and Tichit, M. (2018). Review: make ruminants green again - How can sustainable intensification and agroecology converge for a better future? Animal 12, s210-s219. doi: 10.1017/s1751731118001350

Dumont, B., Petit, M., and D'hour, P. (1995). Choice of sheep and cattle between vegetative and reproductive cocksfoot patches. Appl. Anim. Behav. Sci. 43, 1-15. doi: 10.1016/0168-1591(95)00553-5

Dumont, B., Rossignol, N., Loucougaray, G., Carrère, P., Chadoeuf, J., Fleurance, G., et al. (2012). When does grazing generate stable vegetation patterns in temperate pastures? Agric. Ecosyst. Environ. 153, 50-56. doi: 10.1016/j.agee. 2012.03.003

Figge, F. (2004). Bio-folio: apply portfolio theory to biodiversity. Biodiv. Conserv. 13, 827-849. doi: 10.1023/b:bioc.0000011729.93889.34

Fine, P. E. M. (1993). Herd immunity: history. Theory Pract. Epidem. Rev. 15, 265-302. doi: 10.1093/oxfordjournals.epirev.a036121

Finn, J. A., Kirwan, L., Connolly, J., Sebastià, M. T., Helgadottir, A., Baadshaug, O. H., et al. (2013). Ecosystem function enhanced by combining four functional types of plant species in intensively managed grassland mixtures: a 3-year continental-scale field experiment. J. Appl. Ecol. 50, 365-375. doi: 10.1111/ 1365-2664.12041

Fleurance, G., Farruggia, A., Lanore, L., and Dumont, B. (2016). How does stocking rate influence horse behaviour, performances and pasture biodiversity in mesophile grasslands? Agric. Ecosyst. Environ. 231, 255-263. doi: 10.1016/j. agee.2016.06.044

Food Agriculture and Organisation. (2013). Tackling Climate Change Through Livestock. A Global Assessment of Emissions and Mitigation Opportunities. Rome: FAO.

Forteau, L., Dumont, B., Sallé, G., Bigot, G., and Fleurance, G. (2020). Horses grazing with cattle have reduced strongyle egg count due to the dilution effect and increased reliance on macrocyclic lactones in mixed farms. Animal 14, 1076-1082. doi: 10.1017/s1751731119002738

Fraser, M. D., Moorby, J. M., Vale, J. E., and Evans, D. M. (2014). Mixed grazing systems benefit both upland biodiversity and livestock production. PLoS ONE 9:e89054. doi: 10.1371/journal.pone.0089054

Friggens, N. C., Blanc, F., Berry, D. P., and Puillet, L. (2017). Review: deciphering animal robustness. A synthesis to facilitate its use in livestock breeding and management. Animal 11, 2237-2251. doi: 10.1017/s175173111700088x

García de Jalón, S., Burgess, P. J., Graves, A., Moreno, G., McAdam, J., Pottier, E., et al. (2018). How is agroforestry perceived in Europe? An assessment of positive and negative aspects by stakeholders. Agrofor. Syst. 92, 829-848. doi: 10.1007/s10457-017-0116-3

García-Quirós, A., Arnau-Bonachera, A., Penadés, M., Cervera, C., MartínezParedes, E., Ródenas, L., et al. (2014). A robust rabbit line increases leucocyte counts at weaning and reduces mortality by digestive disorder during fattening. Vet. Immunol. Immunopathol. 161, 123-131. doi: 10.1016/j.vetimm.2014. 07.005

Ginane, C., Baumont, R., Lassalas, J., and Petit, M. (2002). Feeding behaviour and intake of heifers fed on hays of various quality, offered alone or in a choice situation. Anim. Res. 51, 177-188. doi: 10.1051/animres:2002016

Grace, C., Lynch, M. B., Sheridan, H., Lott, S., Fritch, R., and Boland, T. M. (2019). Grazing multispecies swards improves ewe and lamb performance. Animal 13, 1721-1729. doi: 10.1017/s1751731118003245
Hamilton, W. D., Axelrod, R., and Tanese, R. (1990). Sexual reproduction as an adaptation to resist parasites (a review). Proc. Natl. Acad. Sci. U.S.A. 87, 3566-3573. doi: 10.1073/pnas.87.9.3566

Hansson, H., Ferguson, R., and Olofsson, C. (2010). Understanding the diversification and specialization of farm businesses. Agric. Food Sci. 19, 269283.

Harrison, M. T., Evans, J. R., Dove, H., and Moore, A. D. (2011). Dual-purpose cereals: can the relative influences of management and environment on crop recovery and grain yield be dissected? Crop Past. Sci. 62, 930-946.

Haughey, E., Sutter, M., Hofer, D., Hoekstra, N. J., McElwain, J. C., Lüscher, A., et al. (2018). Higher species richness enhances yield stability in intensively managed grasslands with experimental disturbance. Sci. Rep. 8:15047. doi: 10 . 1038/s41598-018-33262-9

Hoste, H., Jackson, F., Athanasiadou, S., Thamsborg, S. M., and Hoskin, S. O. (2006). The effects of tannin-rich plants on parasitic nematodes in ruminants. Trends Parasitol. 22, 253-261. doi: 10.1016/j.pt.2006.04.004

Jerrentrup, J. S., Komainda, M., Seither, M., Cuchillo-Hilario, M., Wrage-Mönnig, N., and Isselstein, J. (2020). Diverse swards and mixed grazing of cattle and sheep for improved productivity. Front. Sustain. Food Syst. 3:125. doi: 10.3389/ fsufs. 2019.00125

Joly, F., Tulganyam, S., and Hubert, B. (2019). Subsistence or market economy? Assessment of a pastoral system of mongolia twenty years after the fall of socialism. Nomad. People 23, 106-142. doi: 10.3197/np.2019.230106

Kingwell, R. (2011). Managing complexity in modern farming. Aust. J. Agric. Resour. Econ. 55, 12-34. doi: 10.1111/j.1467-8489.2010.00528.x

Kozlowski, M., Szczepkowski, M., Krzysztof, W., Szczepkowska, B., and Piotrowska, I. (2014). Polyculture of juvenile pikeperch (Sander lucioperca L.) and sterlet (Acipenser ruthenus L.) in a recirculating system. Arch. Polish Fish. 22, 237-242.

Kragt, M. E., and Robertson, M. J. (2014). Quantifying ecosystem services trade-offs from agricultural practices. Ecol. Econ. 102, 147-157. doi: 10.1016/j.ecolecon. 2014.04.001

Kremen, C., Iles, A., and Bacon, C. (2012). Diversified farming systems: an agroecological, system-based alternative to modern industrial agriculture. Ecol. Soc. 17, 44-62.

Kuiken, T., Holmes, E. C., McCauley, J., Rimmelzwaan, G. F., Williams, C. S., and Grenfell, B. T. (2006). Host species barriers to influenza virus infections. Science 312, 394-397. doi: 10.1126/science.1122818

Loucougaray, G., Bonis, A., and Bouzillé, J. B. (2004). Effects of grazing by horses and/or cattle on the diversity of coastal grasslands in western France. Biol. Conserv. 116, 59-71. doi: 10.1016/s0006-3207(03)00177-0

López-i-Gelats, F., Milán, M. J., and Bartolomé, J. (2011). Is farming enough in mountain areas? Farm diversification in the Pyrenees. Land Use Pol. 28, 783-791. doi: 10.1016/j.landusepol.2011.01.005

Mace, R. (1990). Pastoralist herd compositions in unpredictable environments: a comparison of model predictions and data from camel-keeping groups. Agric. Syst. 33, 1-11. doi: 10.1016/0308-521x(90)90067-z

Macheboeuf, D., Coudert, L., Bergeault, R., Lalière, G., and Niderkorn, V. (2014). Screening of plants from diversified natural grasslands for their potential to combine high digestibility, and low methane and ammonia production. Animal 8, 1797-1806. doi: 10.1017/s1751731114001785

Magne, M. A., Thénard, V., and Mihout, S. (2016). Initial insights on the performances and management of dairy cattle herds combining two breeds with contrasting features. Animal 10, 892-901. doi: 10.1017/s1751731115002840

Mahieu, M. (2013). Effects of stocking rates on gastrointestinal nematode infection levels in a goat/cattle rotational grazing system. Vet. Parasitol. 198, 136-144. doi: 10.1016/j.vetpar.2013.08.029

Marley, C. L., Fraser, M. D., Davies, D. A., Rees, M. E., Vale, J. E., and Forbes, A. B. (2006). The effect of mixed or sequential grazing of cattle and sheep on the faecal egg counts and growth rates of weaned lambs when treated with anthelmintics. Vet. Parasitol. 142, 134-141. doi: 10.1016/j.vetpar.2006.06.030

Martin, G., Barth, K., Benoit, M., Brock, C., Destruel, M., Dumont, B., et al. (2020). Potential of multi-species livestock farming to improve the sustainability of livestock farms: a review. Agric. Syst. 181:102821. doi: 10.1016/j.agsy.2020. 102821

Martin, G., and Magne, M. A. (2015). Agricultural diversity to increase adaptive capacity and reduce vulnerability of livestock systems against weather 
variability - A farm-scale simulation study. Agric. Ecosyst. Environ. 199, 301311. doi: 10.1016/j.agee.2014.10.006

Martínez-Vallespín, B., Martínez-Paredes, E., Ródenas, L., Cervera, C., Pascual, J. J., and Blas, E. (2011). Combined feeding of rabbit female and young: partial replacement of starch with acid detergent fibre or/and neutral detergent soluble fibre at two protein levels. Livest. Sci. 141, 155-165. doi: 10.1016/j.livsci.2011.05.014

Maxin, G., Graulet, B., Le Morvan, A., Picard, F., Portelli, J., and Andueza, D. (2020). Cover crops as alternative forages for ruminants: nutritive characteristics, in vitro digestibility, methane and ammonia production. Anim. Prod. Sci. 60, 823-832.

Ménard, C., Duncan, P., Fleurance, G., Georges, J. Y., and Lila, M. (2002). Comparative foraging and nutrition of horses and cattle in European wetlands. J. Appl. Ecol. 39, 120-133. doi: 10.1046/j.1365-2664.2002.00693.x

Milstein, A. (2005). Polyculture in aquaculture. Anim. Breed. Abstr. 73, 15N-41N.

Milstein, A., Ahmed, A. F., Masud, O. A., Kadir, A., and Wahab, M. A. (2006). Effects of the filter feeder silver carp and the bottom feeders mrigal and common carp on small indigenous fish species (SIS) and pond ecology. Aquaculture 258, 439-451. doi: 10.1016/j.aquaculture.2006.04.045

Moctezuma-Malagón, A., González-Esquivel, C. E., De la Lanza-Espino, G., and González-Rebeles Islas, C. (2008). A methodology for evaluating the sustainability of inland wetland systems. Aquacult. Int. 16, 525-537. doi: 10. 1007/s10499-007-9163-5

Modernel, P., Picasso, V., Do Carmo, M., Rossing, W. A. H., Corbeels, M., Soca, P., et al. (2019). Grazing management for more resilient mixed livestock farming systems on native grasslands of southern South America. Grass For. Sci. 74, 636-649. doi: 10.1111/gfs. 12445

Moloney, B. J., and Whittington, R. J. (2008). Cross species transmission of ovine Johne's disease from sheep to cattle: an estivate of prevalence in exposed susceptible cattle. Aust. Vet. J. 86, 117-123. doi: 10.1111/j.1751-0813.2008. 00272.x

Niderkorn, V., Martin, C., Le Morvan, A., Rochette, Y., Awad, M., and Baumont, R. (2017). Associative effects between fresh perennial ryegrass and white clover on dynamics of intake and digestion in sheep. Grass For. Sci. 72, 691-699. doi: $10.1111 /$ gfs. 12270

Nozières, M. O., Moulin, C. H., and Dedieu, B. (2011). The herd, a source of flexibility for livestock farming systems faced with uncertainties? Animal 5, 1442-1457. doi: 10.1017/s1751731111000486

Ollion, E., Ingrand, S., Delaby, L., Trommenschlager, J. M., Colette-Leurent, S., and Blanc, F. (2016). Assessing the diversity of trade-offs between life functions in early lactation dairy cows. Livest. Sci. 183, 98-107. doi: 10.1016/j.livsci.2015.11.016

Pekkala, N., Knott, K. E., Kotiaho, J. S., Nissinen, K., and Puurtinen, M. (2014). The effect of inbreeding rate on fitness, inbreeding depression and heterosis over a range of inbreeding coefficients. Evol. Appl. 7, 1107-1119. doi: 10.1111/ eva. 12145

Perrin, A., San Cristobal, M., Milestad, R., and Martin, G. (2020). Identification of resilience factors of organic dairy cattle farms. Agric. Syst. 183:102875. doi: 10.1016/j.agsy.2020.102875

Peterson, C. A., Eviner, V. T., and Gaudin, A. C. M. (2018). Ways forward for resilience research in agroecosystems. Agric. Syst. 162, 19-27. doi: 10.1016/j. agsy.2018.01.011

Phocas, F., Belloc, C., Bidanel, J., Delaby, L., Dourmad, J. Y., Dumont, B., et al. (2016). Review: towards the agroecological management of ruminants, pigs and poultry through the development of sustainable breeding programmes: I- selection goals and criteria. Animal 10, 1749-1759. doi: 10.1017/ s1751731116000926

Ponisio, L. C., M’Gonigle, L. K., Mace, K. C., Palomino, J., de Valpine, P., and Kremen, C. (2015). Diversification practices reduce organic to conventional yield gap. Proc. Royal Soc. B 282:20141396. doi: 10.1098/rspb.2014. 1396

Rauw, W. M., Rydhmer, L., Kyriazakis, I., Øverland, M., Gilbert, H., Dekkers, J. C. M., et al. (2020). Prospects for sustainability of pig production in relation to climate change and novel feed resources. J. Sci. Food Agric. 100, 3575-3586. doi: 10.1002/jsfa.10338

Roca-Fernández, A. I., Peyraud, J. L., Delaby, L., and Delagarde, R. (2016). Pasture intake and milk production of dairy cows rotationally grazing on multi-species swards. Animal 10, 1448-1456. doi: 10.1017/s1751731116000331
Rodgo, T., Hektoen, L., Slettemeås, J. S., Jørgensen, H. J., Østerås, O., and Fjeldaas, T. (2012). Possible cross-infection of Dichelobacter nodosus between co-grazing sheep and cattle. Acta Vet. Scand. 54:19.

Romera, A. J., Doole, G. J., Beukes, P. C., Mason, N., and Mudge, P. L. (2017). The role and value of diverse sward mixtures in dairy farm systems of New Zealand: an exploratory assessment. Agric. Syst. 152, 18-26. doi: 10.1016/j.agsy.2016.12.004

Ryschawy, J., Dumont, B., Therond, O., Donnars, C., Hendrickson, J., Benoit, M., et al. (2019). Review: an integrated graphical tool for analysing impacts and services provided by livestock farming. Animal 13, 1760-1772. doi: 10.1017/ s1751731119000351

Sands, B., and Wall, R. (2018). Sustained parasiticide use in cattle farming affects dung beetle functional assemblages. Agric. Ecosyst. Environ. 265, 226-235. doi: 10.1016/j.agee.2018.06.012

Savietto, D., Ródenas, L., Martínez-Paredes, E., Martínez-Vallespín, B., GarcíaDiego, F. J., Fernández, C., et al. (2012). Doe genetic origin, environmental conditions during lactation and kit survival during the fattening period. World Rabbit Sci. 20, 176-177.

Sehested, J., Søegaard, K., Danielsen, V., Roepstorff, A., and Monrad, J. (2004). Grazing with heifers and sows alone or mixed: herbage quality, sward structure and animal weight gain. Livest. Prod. Sci. 88, 223-238. doi: 10.1016/j.livprodsci. 2003.11.008

Silva, J. G. D., Ruviaro, C. F., and Ferreira Filho, J. B. S. (2017). Livestock intensification as a climate policy: lessons from the Brazilian case. Land Use Pol. 62, 232-245. doi: 10.1016/j.landusepol.2016.12.025

Skiftesvik, A., Bjelland, R. M., Durif, C. M. F., Johansen, I. S., and Browman, A. H. (2013). Delousing of Atlantic salmon (Salmo salar) by cultured vs. wild ballan wrasse (Labrus bergylta). Aquaculture 402, 113-118. doi: 10.1016/j.aquaculture. 2013.03.032

Smith, M. E., Linnell, J. D. C., Odden, J., and Swenson, J. E. (2000). Review of methods to reduce livestock depradation: I. Guardian animals. Acta Vet. Scand. 50, 279-290. doi: 10.1080/090647000750069476

Sneessens, I., Sauvée, L., Randrianasolo-Rakotobe, H., and Ingrand, S. (2019). A framework to assess the economic vulnerability of farming systems: application to mixed crop-livestock systems. Agric. Syst. 176:102658. doi: 10.1016/j.agsy. 2019.102658

Speranza, C. I., Wiesmann, U., and Rist, S. (2014). An indicator framework for assessing livelihood resilience in the context of social-ecological dynamics. Global Environ. Change 28, 109-119. doi: 10.1016/j.gloenvcha.2014.06.005

Thornton, P. K. (2010). Livestock production: recent trends, future prospects. Philos. Trans. R. Soc. B 365, 2853-2867. doi: 10.1098/rstb.2010.0134

Tichit, M., Puillet, L., Sabatier, R., and Teillard, F. (2011). Multicriteria performance and sustainability in livestock farming systems: functional diversity matters. Livest. Sci. 139, 161-171. doi: 10.1016/j.livsci.2011.03.006

Valenti, W. C., Kimpara, J. M., de, L., Preto, B., and Moraes-Valenti, P. (2018). Indicators of sustainability to assess aquaculture systems. Ecol. Indic. 88, 402413. doi: 10.1016/j.ecolind.2017.12.068

van der Werf, H. M. G., Trydeman Knudsen, M., and Cederberg, C. (2020). Towards better representation of organic agriculture in life cycle assessment. Nat. Sustain. 3, 419-425. doi: 10.1038/s41893-020-0489-6

Vermeulen, S. J., Dinesh, D., Howden, S. M., Cramer, L., and Thornton, P. K. (2018). Transformation in practice: a review of empirical cases of transformational adaptation in agriculture under climate change. Front. Sustain. Food Syst. 2:65. doi: 10.3389/fsufs.2018.00065

Veysset, P., Lherm, M., Bébin, D., and Roulenc, M. (2014). Mixed croplivestock farming systems: a sustainable way to produce beef? Commercial farms results, questions and perspectives. Animal 8, 1218-1228. doi: 10.1017/ s1751731114000378

Volaire, F., Barkaoui, K., and Norton, M. (2014). Designing resilient and sustainable grasslands for a drier future: adaptive strategies, functional traits and biotic interactions. Eur. J. Agron. 52, 81-89. doi: 10.1016/j.eja.2013. 10.002

Vollet, D., and Said, S. (2018). Vers l'identification de paniers de biens et de services liée à la demande locale dans les territoires d'élevage: illustration à partir de la Planèze de Saint Flour et du bocage bourbonnais. Géocarrefour 92. doi: 10.4000/geocarrefour.11155

Wahab, M. A., Kadir, A., Milstein, A., and Kunda, M. (2011). Manipulation of species combination for enhancing fish production in polyculture systems 
involving major carps and small indigenous fish species. Aquaculture 321, 289-297. doi: 10.1016/j.aquaculture.2011.09.020

Walker, B., Holling, C. S., Carpenter, S. R., and Kinzig, A. (2004). Resilience, adaptability and transformability in social-ecological systems. Ecol. Soc. 9:5.

Walker, B. H., Carpenter, S. R., Rockstrom, J., Crépin, A. S., and Peterson, G. D. (2012). Drivers, "slow" variables, "fast" variables, shocks, and resilience. Ecol. Soc. 17:30.

Wang, L., Delgado-Baquerizo, M., Wang, D., Isbell, F., Liu, J., Feng, C., et al. (2019). Diversifying livestock promotes multidiversity and multifunctionality in managed grasslands. Proc. Natl. Acad. Sci. U.S.A. 116, 6187-6192. doi: 10. 1073/pnas.1807354116

Wright, I. J., Reich, P. B., Westoby, M., Ackerly, D. D., Baruch, Z., Bongers, F., et al. (2004). The worldwide leaf economics spectrum. Nature 428, 821-827.

Yang, L. N., Pan, Z. C., Zhu, W., Wu, E. J., He, D. C., Yuan, X., et al. (2019). Enhanced agricultural sustainability within-species diversification. Nature Sustain. 2, 46-52. doi: 10.1038/s41893-018-0201-2 zu Ermgassen, E. K. H. J., de Alcântara, M. P., Balmford, A., Barioni, L., Beduschi Neto, F., Bettarello, M. M. F., et al. (2018). Results from on-the-ground efforts to promote sustainable cattle ranching in the Brazilian Amazon. Sustainability 10:1301. doi: 10.3390/su10041301

Conflict of Interest: The authors declare that the research was conducted in the absence of any commercial or financial relationships that could be construed as a potential conflict of interest.

Copyright () 2020 Dumont, Puillet, Martin, Savietto, Aubin, Ingrand, Niderkorn, Steinmetz and Thomas. This is an open-access article distributed under the terms of the Creative Commons Attribution License (CC BY). The use, distribution or reproduction in other forums is permitted, provided the original author(s) and the copyright owner(s) are credited and that the original publication in this journal is cited, in accordance with accepted academic practice. No use, distribution or reproduction is permitted which does not comply with these terms. 